\title{
Affordable dye sensitizer by waste
}

\author{
Harsasi Setyawati ${ }^{1}$ Handoko Darmokoesoemo ${ }^{1} \cdot$ Faidur Rochman $^{1} \cdot$ \\ Ahmadi Jaya Permana ${ }^{1}$
}

Received: 22 October 2016/Accepted: 27 August 2017/Published online: 31 August 2017

(c) The Author(s) 2017. This article is an open access publication

\begin{abstract}
The development of dye sensitizer is growing in line with the increasing demand for renewable energy. A research to obtain a dye sensitizer that is economical, safe, and produces a great value of DSSC efficiency is a challenge unresolved. On the other hand, the efforts for waste reduction are also intensively conducted to create better environment. In this paper, the variation of synthetic dye wastes from batik industries have been successfully applied as dye sensitizer and fabricated on DSSC cells. Congo red $(1.0133 \%)$ yielded higher efficiency than rhodamine B $(0.0126 \%)$, methyl orange $(0.7560 \%)$, and naphthol blue black $(0.0083 \%)$. The divergence of the efficiency of DSSC is very dependent upon the chromophore group owned by dye. This study has proven that the more chromophore group possessed by dye, the higher the efficiency of DSSC generated. This research concludes that the dye wastes have a bright future to be implemented as dye sensitizer on solar cells.
\end{abstract}

Keywords Affordable - Batik waste - Dye sensitizer . DSSC $\cdot$ Chromophore

\section{Introduction}

Batik industries in Indonesia are great contributors of liquid waste originating from the dyeing process. During the production process, about $10-15 \%$ of the dye will be

Harsasi Setyawati

harsasi85@gmail.com

1 Department of Chemistry, Faculty of Science and Technology, Airlangga University, 60115 Surabaya, Indonesia released into the environment and causing environmental pollution [1]. In addition to substances of high color, batik and textile industry waste contain synthetic ingredients poorly soluble or hard to decompose. Coloring process in batik will produce cloudy and dark liquid waste. Usually the color of liquid waste depends on the dye used [2]. Actually, dye compounds in aquatic environments can decompose naturally by the presence of sunlight. However, the reaction is relatively slow because the intensity of UV light reaching the earth surface is relatively low. In addition, the energy needs of the world prompted many researchers to pursue alternative renewable energy such as DSSC. DSSC is promising renewable energy resource because of zero waste, low cost and eco-friendly [3-5]. DSSC is a solar cell that utilizes a sensitized dye to harvest sunlight [6]. The dye plays important role to harvest solar energy and convert it to electrical energy [7, 8]. The effort to combine the dye wastes as a dye sensitizer on DSSC is a novel solution to overcome the problem of waste and energy at once. In this research, dye wastes from batik home industries in Indonesia (congo red, rhodamine B, methyl orange, naphthol blue black) are applied as dye sensitizer on DSSC. Thin layer titanium dioxide is used as semiconductor and prepared in various synthesis methods. $\mathrm{KI}_{3}$ is used as electrolyte and graphite as counter electrode. FTO glass is used in the body of DSSC cell.

\section{Experimental}

All chemicals were purchased from commercial sources (Sigma Aldrich) except liquid dye wastes which were collected from batik home industries in Indonesia. The dye wastes were rhodamine $\mathrm{B}$, congo red, methyl orange, and naphthol blue black. Materials for preparation of DSSC 
Table 1 The maximum wavelength of dye wastes matched with color theory [12]

\begin{tabular}{llll}
\hline Dye & $\lambda \max (\mathrm{nm})$ & Absorbed color & Complementary color \\
\hline Rhodamine B & 554 & Green & Red \\
Congo red & 498 & Green & Red \\
Methyl orange & 464 & Blue & Orange \\
Naphthol blue black & 619 & Orange & Blue \\
\hline
\end{tabular}

were titanium(IV) isopropoxide $\left(\mathrm{Ti}\left(\mathrm{OC}_{3} \mathrm{H}_{7}\right)_{4}\right)$ (TTIP), 4-(1,1,3,3-tetramethylbutyl) phenylpolyethylene glycol (Triton $\mathrm{X}-100)$, iodine $\left(\mathrm{I}_{2}\right)$, potassium iodide $(\mathrm{KI})$, ethanol $\left(\mathrm{CH}_{2} \mathrm{CH}_{3} \mathrm{OH}\right)$, hydrochloric acid $(\mathrm{HCl})$, ether and acetic acid $\left(\mathrm{CH}_{3} \mathrm{COOH}\right)$. Fluorine doped tin oxide (FTO) $(10 \Omega$, $25 \times 25 \times 3.2 \mathrm{~mm}$ ) was used as the conductive glass plate and purchased from Latech scientific supply Pte. Ltd Singapore. The top and the left of FTO glass was isolated by adhesive tape about $0.5 \mathrm{~cm}$ for the clamp side and to control the thickness of the coating of $\mathrm{TiO}_{2}$. Graphite was used as a counter electrode.

\section{Preparation of semiconductor}

In this study, synthesis of semiconductor (titanium dioxide) was done by two techniques. First, thin film of titanium dioxide was prepared using surfactants triton X-100 by solgel method. Second, thin film of titanium dioxide was prepared without surfactants triton X-100 by sol-gel method. First technique, $5 \mathrm{~mL}$ of triton $\mathrm{X}-100$ was added into acetic acid and transferred into a $225 \mathrm{~mL}$ ethanol while being stirred for $3 \mathrm{~min}$. Then $15 \mathrm{~mL}$ TTIP was added to $1 \mathrm{~mL}$ of concentrated hydrochloric acid in the solution. The mixture was stirred for $2 \mathrm{~h}$ to form a sol [9]. In the second technique, $15 \mathrm{~mL}$ TTIP in $1 \mathrm{~mL}$ of concentrated hydrochloric acid in the solution was stirred for $2 \mathrm{~h}$ to form a sol.

\section{Preparation of working electrode}

First, the FTO glasses were washed with deionized water and then dried at $80{ }^{\circ} \mathrm{C}$ for $10 \mathrm{~min}$. The conductive side of the FTO glass was covered on two edges with adhesive tape to control the thickness of $\mathrm{TiO}_{2}$ film. Subsequently, the FTO glass was coated with $\mathrm{TiO}_{2}$ sol 3 times. Then each FTO glass was dried at $80^{\circ} \mathrm{C}$ for $10 \mathrm{~min}$. In the last coating, FTO glasses were calcined at $450{ }^{\circ} \mathrm{C}$ for $2 \mathrm{~h}$ and then cooling down in ambient temperature [10]. The electrode was immersed in the each solution of dye $\left(0.1 \mathrm{mmol} \mathrm{L}^{-1}\right)$ for $24 \mathrm{~h}$ at room temperature and then dried [11]. The dyes were congo red, rhodamine B, methyl orange and naphthol blue black.

\section{Preparation of counter electrode}

The counter electrode was prepared by coating the conductive side of FTO glass with carbon from a graphite pencil until evenly distributed. Then, FTO glasses were heated at $450{ }^{\circ} \mathrm{C}$ for $30 \mathrm{~min}$ and then washed and dried. Graphite was chosen as a counter electrode because less costly and easily prepared.

\section{Fabrication of DSSC cells}

Before the working electrode and counter electrode were assembled, the electrolyte solution was prepared by dissolving the iodium $\left(\mathrm{I}_{2}\right)$ into potassium iodide $(\mathrm{KI})$ solution until formed $\mathrm{KI}_{3}$. The DSSC cells were assembled by sandwiched working electrode and counter electrodes, respectively, and then sealed with crocodile clips.

\section{Characterizations}

The maximum wavelength of each synthetic dye was measured using UV-VIS Shimadzu 1800. The functional groups and infrared spectra were recorded using Jasco FTIR 5300. The electrical conductivity of dye was analyzed using

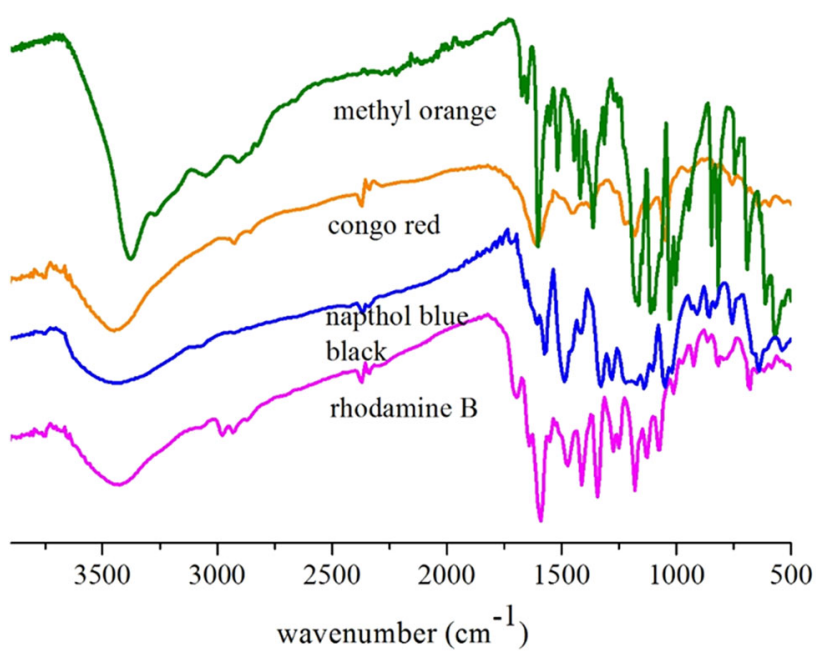

Fig. 1 FTIR spectra of dye wastes 
Table 2 The functional groups of dye wastes and the wavenumber

\begin{tabular}{|c|c|c|c|c|c|c|c|}
\hline \multicolumn{2}{|l|}{ Methyl orange } & \multicolumn{2}{|l|}{ Congo red } & \multicolumn{2}{|c|}{ Naphthol blue black } & \multicolumn{2}{|l|}{ Rhodamine } \\
\hline $\begin{array}{l}\text { Functional } \\
\text { groups }\end{array}$ & $\begin{array}{l}\text { Wave number } \\
\left(\mathrm{cm}^{-1}\right)\end{array}$ & $\begin{array}{l}\text { Functional } \\
\text { groups }\end{array}$ & $\begin{array}{l}\text { Wavenumber } \\
\left(\mathrm{cm}^{-1}\right)\end{array}$ & $\begin{array}{l}\text { Functional } \\
\text { groups }\end{array}$ & $\begin{array}{l}\text { Wavenumber } \\
\left(\mathrm{cm}^{-1}\right)\end{array}$ & $\begin{array}{l}\text { Functional } \\
\text { groups }\end{array}$ & $\begin{array}{l}\text { Wavenumber } \\
\left(\mathrm{cm}^{-1}\right)\end{array}$ \\
\hline $\mathrm{C}=\mathrm{C}$ aromatic & $1604.77[13]$ & $\mathrm{C}=\mathrm{C}$ aromatic & $1612[14]$ & $\mathrm{C}=\mathrm{C}$ aromatic & $1573.91[15]$ & $\mathrm{C}=\mathrm{C}$ aromatic & $1589.34[13]$ \\
\hline $\mathrm{RSO}_{3}{ }^{-}$ & $1118.71[13]$ & $\mathrm{RSO}_{3}{ }^{-}$ & $1149.28[14]$ & $\mathrm{RSO}_{3}{ }^{-}$ & $1141.86[16]$ & $\mathrm{C}-\mathrm{H}$ aromatic & 925.83 [13] \\
\hline \multirow[t]{5}{*}{$\mathrm{N}=\mathrm{N}$} & $1365.60[13]$ & $\mathrm{N}=\mathrm{N}$ & $1458.15[14]$ & $\mathrm{N}=\mathrm{N}$ & $1419.61[17]$ & $\mathrm{Cl}-$ & $794.67[18]$ \\
\hline & & $\mathrm{NH}_{2}$ & $3448.72[14]$ & $\mathrm{NH}_{2}$ & $3749.62[17]$ & $\mathrm{C}=\mathrm{N}$ & $1342.46[13]$ \\
\hline & & $\mathrm{C}-\mathrm{S}$ & $594.08[14]$ & $\mathrm{NO}_{2}$ & $1489.05[17]$ & $-\mathrm{CH} 3$ & 1411.89 [13] \\
\hline & & & & $\mathrm{O}-\mathrm{H}$ & 3441.01 [19] & $\mathrm{C}=\mathrm{O}$ & $1697.36[13]$ \\
\hline & & & & & & $\mathrm{O}-\mathrm{H}$ & $3425.58[13]$ \\
\hline
\end{tabular}<smiles>NC1=C2OS(=O)(=O)C1=Cc1c(cc(S(=O)(=O)O)c(N=Nc3ccc([N+](=O)[O-])cc3)c1O)C=C2S(=O)(=O)O</smiles>

Napthol blue black<smiles>CN(C)c1ccc(/N=N/c2ccc(S(=O)(=O)O[Na])cc2)cc1</smiles>

Methyl orange<smiles>Nc1c(N=Nc2ccc(-c3ccc(N=Nc4cc(S(=O)(=O)[O-])c5ccccc5c4N)cc3)cc2)cc(S(=O)(=O)[O-])c2ccccc12</smiles>

Congo red<smiles>CCN(CC)c1ccc2c(-c3ccccc3C(=O)O)c3ccc(=[N+](CC)CC)cc-3oc2c1</smiles>

Rhodamine B

Fig. 2 Structure of dye wastes

Table 3 Theoretical calculation of the amount of chromophore

\begin{tabular}{|c|c|c|c|c|c|}
\hline \multirow{2}{*}{ Compound } & \multicolumn{5}{|c|}{ Chromophore } \\
\hline & $\mathrm{C}=\mathrm{O}$ & $\mathrm{N}=\mathrm{N}$ & $\mathrm{S}=\mathrm{O}$ & Benzene & $\overline{\text { Total }}$ \\
\hline Methyl orange & 0 & 1 & 2 & 2 & 5 \\
\hline Congo red & 0 & 2 & 4 & 6 & 12 \\
\hline Naphthol blue black & 0 & 2 & 4 & 4 & 10 \\
\hline Rhodamine & 1 & 0 & 0 & 3 & 4 \\
\hline
\end{tabular}

EUTECH conductometer. The crystallinity and phase analysis of two kinds of thin film titanium dioxide was characterized using X'pert PRO Diffractometer. Photovoltaic performance of DSSC cells for each dye sensitizer was measured by measuring current density-voltage curves under solar irradiation in real condition (outdoor) as long as 5 days. The voltage and current density of the cell were measured with multimeter Dekko using potentiometer circuit while intensity of light was measured with Light Meter Krisbow KW06-288.

\section{Results and discussion}

This research successfully developed a novel dye sensitizer from dye wastes. Liquid dye wastes used are rhodamine B, congo red, methyl orange and naphthol blue black obtained from batik industries. At batik home industries, dyeing process is generally done manually by immersion of fabric into the dye in large vat. Each vat containing a particular dye. Liquid dye wastes in the study came from the vat dye 


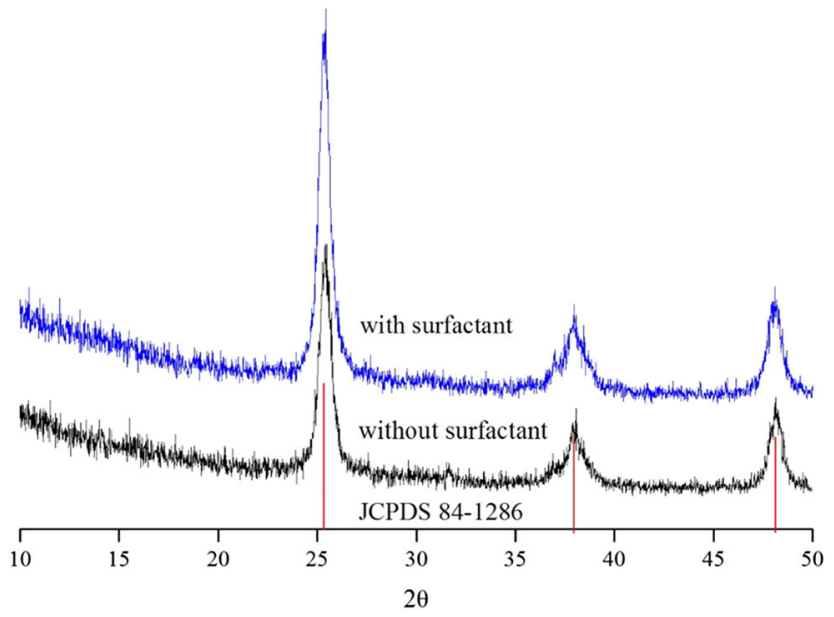

Fig. 3 XRD pattern of thin layer titanium dioxide as semiconductor on DSSC

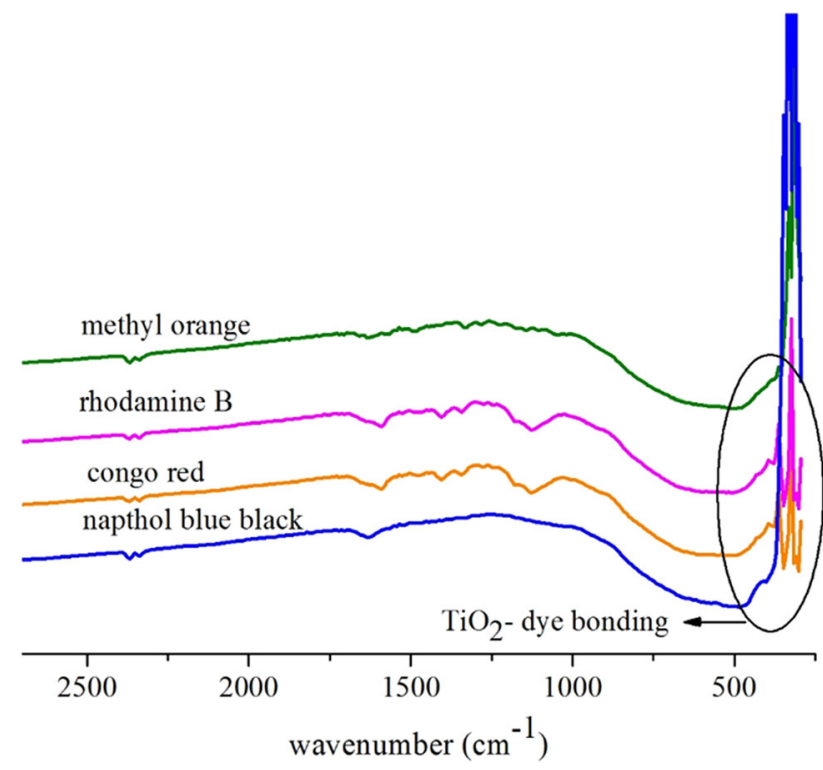

Fig. 4 FTIR spectra of the interaction bonding of $\mathrm{TiO}_{2}$-dye wastes

that can be ascertained dye waste is not mixed with each other.

\section{Characteristic of dye wastes}

Characterizations of dyes have been done to determine the characteristics of each dye that support their dye sensitizer performance. The result of measurement spectrophotometer UV-VIS is shown in Table 1 . All of dyes show the maximum wavelength in the $400-600 \mathrm{~nm}$ range as the absorbed color is blue-orange. This result indicates that each dye can absorb the visible light from solar light. These properties are very advantageous because the visible energy range is so wide that allows many levels of energy to be absorbed by the dyes [11].

Figure 1 shows the fourier transform infrared spectra of rhodamine $\mathrm{B}$, congo red, methyl orange and naphthol blue black. The spectra have been recorded using Jasco FTIR 5300 in the wave number range $500-4000 \mathrm{~cm}^{-1}$. Each dye has specific functional group and is tabulated in Table 2.

Table 2 shows that each dye has chromophore group in their structure which is able to support their performance as dye sensitizer on DSSC. Chromophore is the part of molecule that is sensitive to light $[20,21]$. The chromophore owned by dye will increase the dye's ability for capturing the photon from sunlight so the amount of photon used to generate a cycle of electrons in DSSC cells will increase. This process will generate a continuous electrical current. The number of chromophore groups highly influences the ability of dye on capturing photon of solar light. The more of chromophore groups the more photons absorbed. Thus, the current produced will be higher. Description of the structure and the amount of dye chromophore are presented in Fig. 2 and Table 3.

\section{Characteristic of thin layer $\mathrm{TiO}_{2}$ as semiconductor on DSSC}

Figure 3 shows the result of semiconductor characterization using XRD X'pert PRO Diffractometer. In this work, preparation of thin film titanium dioxide was varied by adding surfactants and without surfactants. The result shows that the patterns of thin film titanium dioxide by adding and without surfactants is similar and refers to the structure of $\mathrm{TiO}_{2}$ anatase according the database JCPDS 84-1286. If we see the intensity, thin film with surfactants is different from that without surfactants. It means that surfactants that added contributed to form structure in film layer titanium dioxide [22, 23].

In DSSC, dye sensitizer was attached to the semiconductor. Therefore, the interaction of $\mathrm{TiO}_{2}$ and dye was characterized using FTIR to determine the bonding of $\mathrm{TiO}_{2}$ and dye. Figure 4 shows that the interaction of $\mathrm{TiO}_{2}$ and dye was chemical interaction of $\mathrm{Ti}$ and $\mathrm{O}$ from dye formed Ti-O bonding at $400-500 \mathrm{~cm}^{-1}$ [18]. This interaction highly supports the flow of electron transfer from dye to the semiconductor $[7,8]$.

\section{Photovoltaic performance}

The performance of dye wastes as dye sensitizer is shown in Fig. 5 and Table 4. The current density-voltage (J-V) curve of dye wastes are shown in Fig. 5. Table 4 shows that congo red yielded the highest efficiency (1.9\%) among 

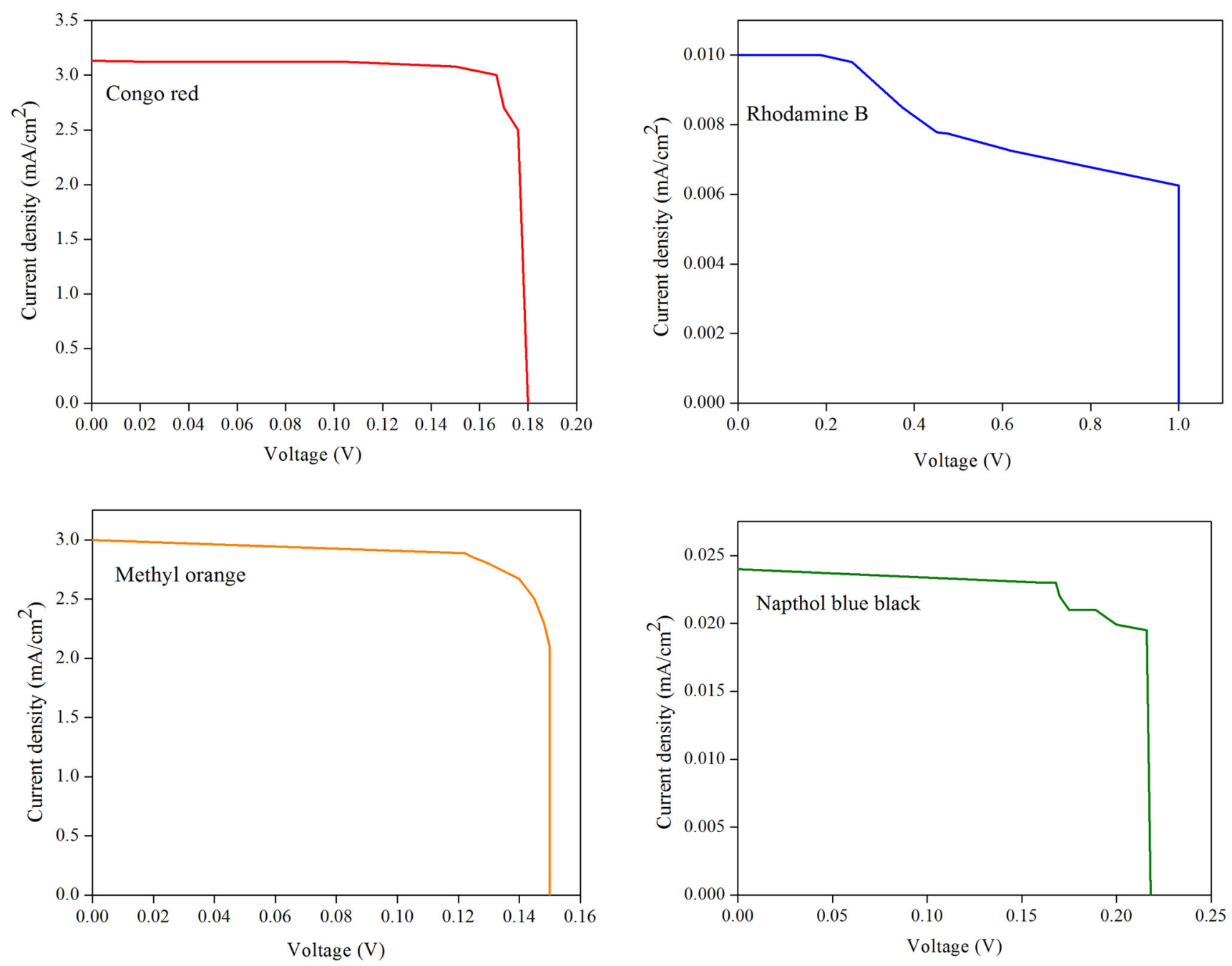

Fig. 5 J-V characteristic curve of dye wastes on DSSC

Table 4 The photovoltaic parameters of the DSSC cells

\begin{tabular}{llllllrr}
\hline Dye & $J_{\mathrm{Sc}}\left(\mathrm{mAcm}^{-2}\right)$ & $V_{\mathrm{oc}}(\mathrm{V})$ & $\mathrm{Jmax}\left(\mathrm{mAcm}^{-2}\right)$ & $\mathrm{Vmax}(\mathrm{V})$ & $\mathrm{P} \operatorname{Lux}\left(\mathrm{W} \mathrm{m}^{-2}\right)$ & $\mathrm{FF}$ & $\eta(\%)$ \\
\hline Congo red & 3.130 & 0.18 & 3 & 0.167 & 49.44 & 0.8892 & 1.0133 \\
Rhodamine B & 0.010 & 1 & 0.00625 & 1 & 49.44 & 0.6250 & 0.0126 \\
Methyl orange & 3 & 0.15 & 2.67 & 0.14 & 49.44 & 0.8306 & 0.7560 \\
Naphthol blue black & 0.024 & 0.218 & 0.019 & 0.216 & 49.44 & 0.7844 & 0.0083
\end{tabular}

Area of DSSC cells: $4 \mathrm{~cm}^{2}$

dyes because congo red has the highest number of chromophore group, i.e., benzene rings, azo $(\mathrm{N}=\mathrm{N})$, and sulfoxide $(\mathrm{S}=\mathrm{O})$. This result indicates that congo red has the best ability in capturing photon from solar energy because of the supporting of their chromophore group. The highest efficiency means that the most photon of solar energy can be absorbed by dye sensitizer [10, 20, 21].

Table 4 shows that dye wastes generate diverse efficiency of DSSC value; the efficiency of DSSC reached is $1.0133 \%$. This value is considerably higher than those of the
DSSC sensitized by other synthetics dyes or natural dyes. Synthetics dyes from hydrazonoyl and their derivatives reported obtain the efficiency of DSSC of 0.00009-0.003\% [24]. Natural dyes from five plants Amaranthus caudatus, Bougainvillea spectabilis, Delonix regia, Nerium oleander and Spathodea campanulata obtained the highest efficiency of DSSC reached $0.610 \%$ from Amaranthus caudatus [25]. Natural dyes from beet, red cabbage, strawberry, spinach, mallow, and henna extract obtained the highest efficiency of $0.229 \%$ [26]. Chlorophyll and xanthophyll from 
Cladophora sp. reported obtained the highest efficiency of $0.08 \%$ [27]. This result indicates that dye waste was potentially applied as dye sensitizer on DSSC.

\section{Conclusion}

In this work, DSSC were assembled using four dye wastes from batik industries in Indonesia as dye sensitizer. Congo red has been proven to yield the highest efficiency among the dye wastes, i.e., $1.0133 \%$. This is because congo red has the most of chromophore group than the other dyes. This study proves that the chromophore group greatly contributes to improving the efficiency of DSSC.

Acknowledgements The authors gratefully acknowledge the financial support provided by the research Grant "Hibah Dosen Muda" sponsored by Faculty of Science and Technology, Airlangga University and Penelitian Unggulan Perguruan Tinggi (PUPT) sponsored by Ministry of Research, Technology and Higher Education (RISTEKDIKTI) and also Department of Chemistry, Faculty of Science and Technology, Airlangga University Surabaya, Indonesia for support the facilities.

Open Access This article is distributed under the terms of the Creative Commons Attribution 4.0 International License (http:// creativecommons.org/licenses/by/4.0/), which permits unrestricted use, distribution, and reproduction in any medium, provided you give appropriate credit to the original author(s) and the source, provide a link to the Creative Commons license, and indicate if changes were made.

\section{References}

1. Amaliasani, R.: Pengolahan Limbah Batik Dengan Menggunakan Metode Elektrolisis Dengan Anoda dan Katoda Platinum (Pt). Universitas Islam Indonesia, Yogyakarta (2013)

2. Suprihatin, H.: Kandungan Organik Limbah Cair Industri Batik Jetis Sidoarjo dan Alternatif Pengolahannya Pusat Penelitian Lingkungan Hidup Universitas Riau (2014)

3. Giribabu, L., Sudhakar, K., Velkannan, V.: Phthalocyanines: potential alternative sensitizers to $\mathrm{Ru}$ (II) polypyridyl complexes for dye-sensitized solar cells. Curr. Sci. 102(7), 991-1000 (2012)

4. Baldenebro-Lopez, J., Flores-Holguin, N., Castorena-Gonzalez, J., Glossman-Mitnik, D.: Molecular design of copper complexes as sensitizers for efficient dye-sensitized solar cells. J. Photochem. Photobiol. A 267, 1-5 (2013). doi:10.1016/j.jphotochem.2013.06.005

5. Bignozzi, C., Argazzi, R., Boaretto, R., Busatto, E., Carli, S., Ronconi, F., Caramori, S.: The role of transition metal complexes in dye sensitized solar devices. Coord. Chem. Rev. 257(9), 1472-1492 (2013)

6. Grätzel, M.: Dye-sensitized solar cells. J. Photochem. Photobiol. C 4(2), 145-153 (2003)

7. Alhamed, M., Issa, A.S., Doubal, A.W.: Studying of natural dyes properties as photo-sensitizer for dye sensitized solar cells (DSSC). J. Electron Devices 16(11), 1370-1383 (2012)

8. Tennakone, K., Kumara, G., Kumarasinghe, A., Sirimanne, P., Wijayantha, K.: Efficient photosensitization of nanocrystalline $\mathrm{TiO}_{2}$ films by tannins and related phenolic substances. J. Photochem. Photobiol. A 94(2), 217-220 (1996)
9. Fagnern, N., Letphayakkarat, R., Chawengkijwanich, C., Gleesom, M.P., Koonsaeng, N., Sanguanruang, S.: Effect of titaniumtetraisopropoxide concentration on the photocatalytic efficiency of textile dyes. J. Phys. Chem. Solid 73, 1483-1486 (2012)

10. Setyawati, H., Darmokoesoemo, H., Hamami, H., Rochman, F., Permana, A.J.: Promising dye sensitizer on solar cell from complexes of metal and rhodamine B. Int. J. Renew. Energy Res. 5(3), 694-698 (2015)

11. Setyawati, H., Purwaningsih, A., Darmokoesoemo, H., Hamami, H., Rochman, F., Permana, A., P: Potential complex of rhodamine B and copper (II) for dye sensitizer on solar cell. In: ICOWOBAS 2015, Indonesia, pp. 070004-1-070004-6. AIP Publishing, New York (2016)

12. Denny, R., Sinclair, R.: Visible and Ultraviolet Spectroscopy, Analytical Chemistry by Open Learning. Wiley, New York (1987)

13. Pavia, D.L., Lampman, G.M., Kriz, G.S., Vyvyan, J.A.: Introduction to Spectroscopy. Cengage Learning, Boston (2008)

14. Pretsch, E., Clerc, T., Seibl, J., Simon, W.: Tables of Determination of Organic Compounds. 13C NMR, 1H NMR, IR, MS, UV/Vis, Chemical Laboratory Practice. Springer-Verlag, Berlin (1989)

15. Farhadyar, N., Rahimi, A., Ershad Langroudi, A.: Synthesis and characterization of inorganic-organic hybrid produced from tetraethoxysilane and epoxy-aromatic amine. In: IUPAC World Polymer Congress Macro, pp. 2 (2004)

16. Pretsch, E., Clerc, T., Seibl, J., Simon, W.: Tables of Spectral Data for Structure Determination of Organic Compounds. Springer Science and Business Media, Berlin (2013)

17. Yuen, C., Ku, S., Choi, P., Kan, C., Tsang, S.: Determining functional groups of commercially available ink-jet printing reactive dyes using infrared spectroscopy. Res. J. Text. Appar. 9(2), 26-38 (2005)

18. Nakamoto, K.: Infrared and raman spectra of inorganic and coordination compounds. In: Handbook of Vibrational Spectroscopy. Wiley, New York (2006). doi:10.1002/0470027320.s4104

19. Duygu, D.Y., Udoh, A.U., Ozer, T.B., Akbulut, A., Erkaya, I.A., Yildiz, K., Guler, D.: Fourier transform infrared (FTIR) spectroscopy for identification of Chlorella vulgaris Beijerinck 1890 and Scenedesmus obliquus (Turpin) Kützing 1833. Afr. J. Biotech. 11(16), 3817-3824 (2012)

20. Qin, P., Wiberg, J., Gibson, E.A., Linder, M., Li, L., Brinck, T., Hagfeldt, A., Albinsson, B., Sun, L.: Synthesis and mechanistic studies of organic chromophores with different energy levels for p-type dyesensitized solar cells. J. Phys. Chem. C 114(10), 4738-4748 (2010)

21. Zhang, G., Bala, H., Cheng, Y., Shi, D., Lv, X., Yu, Q., Wang, P.: High efficiency and stable dye-sensitized solar cells with an organic chromophore featuring a binary $\pi$-conjugated spacer. Chem. Commun. 16, 2198-2200 (2009)

22. Černigoj, U., Štangar, U.L., Trebše, P., Krašovec, U.O., Gross, S.: Photocatalytically active $\mathrm{TiO}_{2}$ thin films produced by surfactant-assisted sol-gel processing. Thin Solid Films 495(1), 327-332 (2006)

23. Inoue, M., Hirasawa, I.: The relationship between crystal morphology and XRD peak intensity on $\mathrm{CaSO}_{4} \cdot 2 \mathrm{H}_{2} \mathrm{O}$. J. Cryst. Growth 380, 169-175 (2013)

24. Abdel-Latif, M.S., Batniji, A., El-Agez, T.M., Younis, M.J., Ghamri, H., Thaher, B.A.A., Qeshta, B.S., Abu-Awwad, F.M., Taya, S.A.: Dye sensitized solar cells based on hydrazonoyl synthetic dyes. J. Nano Electron. Phys. 8(4), 4038 (2016)

25. Godibo, D.J., Anshebo, S.T., Anshebo, T.Y.: Dye sensitized solar cells using natural pigments from five plants and quasi-solid state electrolyte. J. Braz. Chem. Soc. 26(1), 92-101 (2015)

26. Torchani, A., Saadaoui, S., Gharbi, R., Fathallah, M.: Sensitized solar cells based on natural dyes. Curr. Appl. Phys. 15(3), 307-312 (2015)

27. Lim, A., Haji Manaf, N., Tennakoon, K., Chandrakanthi, R., Lim, L.B.L., Bandara, J., Ekanayake, P.: Higher performance of DSSC with dyes from Cladophora sp. as mixed cosensitizer through synergistic effect. J. Biophys. (2015). doi:10.1155/2015/510467 